\title{
Life Cycle Perspective of R\&D Investment Management: Case Study Approach
}

\author{
Marie Kubáňková* - Jaroslava Hyršlová
}

\section{Introduction}

The management of R\&D activities has become popular among researchers (Pearson, 2010; Chiesa, 2009; Jorgesen - Messner, 2010). The need for changes in $R \& D$ organisation and financial support brings new decision-making issues for the R\&D manager (Pearson, 2010). The strategic management accounting (SMA) literature has not devoted much attention to innovation management and the practical use of SMA techniques (Nixon, 2012), there are only a few case studies of a particular SMA instrument used for product development (Nixon, 2012; Jorgesen Messner, 2010) such as target costing (Woods, 2012). Rapid technological change and a shortened life cycle have made life cycle costing central to competitive advantage (Dunk, 2012). R\&D could be considered as a tool for managing "dynamic capabilities" so that the company can secure its position in the turbulent environment (Teece et al., 1997 in Tierlinck, 2013).

Following Pearson's (2010) critique of the lack of research on the operational and strategic level of $R \& D$, precisely $R \& D$ project appraisal criteria and methods that would allow the ex ante evaluation of $R \& D$ cost and profit of the product innovation projects, the paper suggests a measure based on life-cycle approach. The usefulness of proposed tool is tested practically using the case study of a real company. Case study

Ing. Marie Kubáňková - Ph.D. Student; Department of Management Accounting, Faculty of Finance and Accounting, University of Economics, Prague, W. Churchill Sq. 4, 13067 Prague 3, Czech Republic, <mariekubankova@gmail.com>,

** Doc. Ing. Jaroslava Hyršlová, Ph.D. - Associated Professor; Department of Transport Management, Marketing and Logistics, Jan Perner Transport Faculty, University of Pardubice, Studentská 95, $532 \quad 10$ Pardubice, Czech Republic, <jaroslava.hyrslova@upce.cz>. 
methodology has been increasingly used to build knowledge of actual business practices, as the practitioners' views are crucial in any research relating to the practical application (Dixon, 1998). He believes that this method or research is the most appropriate for achieving the research of practical usage of SMA. We share the same opinion; therefore, we decided to use a case study method.

\section{Literary review}

The current global market economic situation makes estimating product life cycle quite difficult, new products are quickly replaced by newer ones. At the same time, the research and development phase is expanding (Back-Hock, 1992). The competitive advantage lies in resources that are not easily measured by traditional financial metrics, such as ongoing research and development (Brown - Svenson, 1998; Kerssens-van Drongelen et al., 2000; Pearson, 2010; Bremser, 2004). Therefore, $R \& D$ managers face challenges when making long-term $R \& D$ plans (Tierlinck, 2013).

Less and less R\&D projects are centrally funded. The situation where each individual project is financed by an individual business unit has prevailed (Pearson, 2010). Therefore R\&D managers face new challenges - how to secure accountability for R\&D costs, revenues, investment decisions and profits and how to balance this with the total financial resources, position, risk profile and expenditure of the company (Pearson, 2010). Evaluation, motivation, operative control and cooperation in new product development projects are the key reasons for monitoring R\&D (Kerssen-van Drongelen et al., 2000). The R\&D process cannot be measured separately any longer; business performance must be measured by integrated performance measurement systems (Bremser, 2004). The aim of $R \& D$ performance measurement systems is to move from integrating past-oriented data to prospective long-term strategic and financial metrics (Bremser, 2004). In the current competitive climate R\&D expenditure must be managed and evaluated with the estimated benefits of the R\&D results (Pearson, 2010). The measurement of $R \& D$ must reflect the organisation management and culture and it should support the decision-making process at the same time (Pearson, 2010). $R \& D$ managers should combine external and internal changes (i.e. imperfect knowledge of what is going on inside and outside the firm) and continuously adapt their R\&D management (Tidd - Bessant, 2009 in 
Kubáňková, M. - Hyršlová, J.: Life Cycle Perspective of $R \& D$ Investment Management: Case Study Approach.

Tierlinck, 2013). This coordination presupposes a strong commitment of the internal R\&D staff.

This new development also requires a strategic perspective on product accounting, as the traditional accounting frameworks are designed for predetermined time intervals such as months, quarters and year (BackHock, 1992). Management must realize the importance of the lifetime cost perspective and the decision-making process of $R \& D$ investment will be rather considered in the long-term and life-cycle perspective. Woodward (1997) suggests that project managers should familiarise themselves with what the approach involves, to better appreciate how they might contribute to the enhanced quality decision-making. Guilding (2000) adds the need for larger picture in strategic decision-making process, long-term objectives and an adequate recourses allocation.

\section{Reference framework}

\subsection{Key questions for $R \& D$ management}

Accountants and accounting techniques are predisposed to regard the freedom needed for creativity and innovative $R \& D$ as an underutilisation of resources and a target for cost-cutting (Lothian, 1984 in Pearson, 2010). Traditional accounting approaches limit especially the possibility of evaluating the effectiveness of products with shorter life cycles (BackHock, 1992). The traditional way of recovering the cost of R\&D projects has usually been a cost-plus basis (Pearson, 2010). Back-Hock (1992) names two key questions associated with $R \& D$ where the financial accounting provides a lack of information:

- Will a product cover its currently accumulated and expected direct development costs?

- Will the accrued contributions of a product cover the necessary investments to develop a follow- up product?

Setting the structure of $R \& D$ from early research to life-cycle management helps to manage the R\&D process (Pearson, 2010). The life cycle perspective answers the above questions (Back-Hock, 1992). The term "life cycle" has a long history and it is used in many disciplines and meanings - organisms have a life cycle, businesses have one, and so do 
policies and technologies (Heijungs, 2010). Heijung (2010) classifies several meanings of product life cycles:

- from the design point of view - starting with idea generation and ending with commercialization;

- from the entrepreneurial perspective - starting with market crystallization and ending with market termination;

- from the cost calculation perspective - starting with R\&Dcosts and ending with disposal cost.

While the traditional life cycle cost concept identifies life cycle phases: initiation, planning, design and construction, realization, operation, disposal/salvage (Wubbenhorst, 1986; Harvey, 1976 in BackHock, 1992); a life cycle calculation is based on an expanded life cycle perspective and thus considers not only investment costs but also operating costs during the product's estimated lifetime (Gluch Baumann, 2004).

\subsection{Product life cycle management systems}

This is an SMA concept that provides instruments in response to the traditional cost accounting techniques that have been criticized for their failure to support adequately decision-making in an environment of evershorter product life cycles (Back-Hock, 1992; Bhimani, 2007). Roslender (2003) defines SMA as a generic approach to accounting for strategic positioning, characterised by the attempt to integrate insights from marketing literature into management accounting. Roslender argues that the generic SMA approach encompasses Porter's competitive advantage theory and in particular, his strategic cost analysis technique (Porter, 1985 in Roslender, 2003), together with both target costing and life-cycle costing. SMA examines structured data on the competitive advantage from long-term planning and decision-making purposes and systems incorporating product development using various techniques such as lifecycle based strategic accounting, target and kaizen costing or product life cycle management systems (Nixon, 2012; Bhimani, 2007). Target costing and life cycle costing can be regarded as relatively modern advances in management accounting, so it is worth first looking at the approach taken by conventional costing (Woods, 2012). Back-Hock (1992) defines 
Kubáňková, M. - Hyršlová, J.: Life Cycle Perspective of $R \& D$ Investment Management: Case Study Approach.

Product life cycle accounting as a strategic accounting perspective on product management.

\subsection{Life cycle costing (LCC)}

Král et al. (2002) defines the advantages of LCC for R\&D cost management saying that $R \& D$ cost can be classified as an investment cost and treated accordingly when LCC can also cover the cost of the pre production phase. Šoljaková (2007) defines LCC as a tool for strategic management for costs, revenues and profit setting during the whole life cycle of the product. LCC calculates the total costs of a product, process or activity over its life span (Jeswani, 2010).

Gluch and Baumann (2004) discussed LCC from the perspective of how useful and appropriate the LCC approach is for environmental decision-making. Authors conclude:

- even if not theoretically accurate, the results on an LCC calculation might provide at least an indication of what strategic decisions should be made;

- from a user perspective it seems to be a good idea to link environmental issues with financial consequences when implementing environmental issues in a corporate decisionmaking context;

- a life cycle perspective is good since it extends the system boundaries and incorporates some costs that occur in the future.

Jeswani (2010) accents the possibility of identifying economic 'hotspots' with LCC if it is set up as a value added analysis.

\section{Research methodology}

In 2013, the national Czech media gave large coverage to the huge problem of bee colonies devastation caused by a long winter and a virus. The alternative for pollinating some plants could be bumblebees. 
A search was instigated among bumblebee producers and a private SME company ("Company A") was set up. Company A produces seeds, new agriculture technologies and provides consultancy services for farmers. Company A has been operating on the Czech market for 24 years, it has its own R\&D department and has invested large resources in researching and developing new products and technologies. In 2013 a new investment project for laboratory bumblebee farming started. The aim of the project is to produce bumblebee nests for farmers and the target is to enter the market in the 2014 season. We decided to use this practical example and examine if LCC is an effective tool for managing investment in $\mathrm{R} \& \mathrm{D}$ and if it can provide a complete evaluation of the R\&D investment. We decided to use the LCC model because it can be used to evaluate the effectiveness of an $R \& D$ investment in a new product. We also want to reflect the growing interest in practice theory approaches within management and organisation studies (Ahrens Chapman, 2007; Jarzabkowski, 2004; Orlikowski, 2007; Schatzki, 2005; Whittington, 2006 in Jorgensen - Messner, 2010) therefore we have decided to use a case study method.

A search of case study layout and topic was carried out and several papers were examined, mainly the following - see Tab. 1 .

\section{Tab. 1: Application of case study}

\begin{tabular}{|l|l|l|}
\hline \multicolumn{1}{|c|}{ Author } & \multicolumn{1}{|c|}{ Aim of the research } & Characterization of method \\
\hline $\begin{array}{l}\text { Bhimani } \\
(2007)\end{array}$ & $\begin{array}{l}\text { Structure of the strategy } \\
\text { development process, financial } \\
\text { and non-financial information }\end{array}$ & $\begin{array}{l}5 \text { companies, semi - structured } \\
\text { interviews - 5 questions }\end{array}$ \\
\hline $\begin{array}{l}\text { Jorgensen } \\
\text { and } \\
\text { Messner } \\
(2010)\end{array}$ & $\begin{array}{l}\text { The relationship between strategy } \\
\text { and accounting }\end{array}$ & $\begin{array}{l}1 \text { company, 16 months, 28 } \\
\text { interviews, review of } \\
\text { documents (management } \\
\text { reports, strategy documents, } \\
\text { consulting reports etc. })\end{array}$ \\
\hline Seal (2010) & $\begin{array}{l}\text { Impact of ROI, value based } \\
\text { management and SMA on } \\
\text { managerial discourse and practice }\end{array}$ & $\begin{array}{l}\text { company, empirically } \\
\text { contextualised exam through } \\
\text { case history }\end{array}$ \\
\hline $\begin{array}{l}\text { Chiesa } \\
(2009)\end{array}$ & $\begin{array}{l}\text { The impact of a performance } \\
\text { management system objective on } \\
\text { its constructive elements }\end{array}$ & $\begin{array}{l}15 \text { companies, semi - structured } \\
\text { interviews - 6 questions, review } \\
\text { of documents }\end{array}$ \\
\hline
\end{tabular}

Source: Authors' processing. 
Kubáňková, M. - Hyršlová, J.: Life Cycle Perspective of $R \& D$ Investment Management: Case Study Approach.

From these papers, a decision for a case study of Company A was taken consisting of the following steps:

1. We presented our project to the general manager who supported our plan and was involved in the research. The general manager introduced us to the financial manager and $R \& D$ manager who were both available during the research.

2. The following questions were prepared for the scheduled interviews on the following topics:

a) the decision-making process of the $R \& D$ investment (for the general manager):

- Who makes the final decision on an R\&D project?

- What are the key factors for the investment decision?

- What is the main reason for the new product development of laboratory bumblebee farming?

- What is the main advantage of the new product?

b) the research on the new technology of laboratory bumblebee farming (for the R\&D manager):

- What is the main advantage of the new product?

- Would it be necessary to continue investing in a follow up project in the foreseeable future? If so, when?

c) finance and marketing issues (for the finance manager and marketing manager):

- What is the proposed selling price of the new product?

- What are the estimated production costs of the new product? How were the costs calculated?

- How will the distribution be organised?

- Does the company have a sales and marketing budget? 
A memo was taken from each interview and it was approved by the respondent, the research protocol is in Appendix 1. We have compiled a list of documents that the company has provided, i.e. the financial statements for 2011 and 2012 and interim statements for 2013; we also had access to the laboratory research project of breeding bumblebee nests, which was created by the $R \& D$ department for the internal use of the company and selected meeting minutes of the company's management. These documents helped us to check the data obtained through the interviews.

3. After reviewing the documents, we designed tools to measure the effectiveness of the R\&D investment and prepared the LCC version, which was presented to the general manager, $R \& D$ manager and financial manager.

\section{The case study}

\subsection{Decision-making process about $R \& D$ investment}

The results of the interviews show that the main reason for the $R \& D$ investment is market demand. As the Company A is not a monopoly setting the strategy is done very carefully and decisions are based primarily on historical data. Company shareholders set the profit and cash flow targets for next year. These targets are reflected in the master budget and performance is regularly monitored during the financial year.

The investment decision-making process is based primarily on data from financial forecasts; the two key factors are a qualitative assessment of the R\&D project and the available financial resources. The investment in bumblebee farming laboratory was approved according to the financial result of 2011 and 2012 and also the forecast for 2013 (see Appendix 2).

The investment in new technology for producing bumblebee nests was EUR 20.020 in 2013 and EUR 19.980 in 2014. The project will be completed in 2014 and the product introduced on the market. At the moment, the current technology will not protect the newly produced bumblebee nests against all viruses. Therefore, a further investment should be made in 2017. 
Kubáňková, M. - Hyršlová, J.: Life Cycle Perspective of R\&D Investment Management: Case Study Approach.

\subsection{Investment appraisal techniques}

We decided to use the NPV (net present value) method to evaluate the investments in $\mathrm{R} \& \mathrm{D}$ over the life-cycle of the product according to the research findings presented by Carr (2010). He points out the relationship of the financial indicator and the company type. Carr (2010) distinguishes between market creators, value creators, restructurers and refocusers. His finding are summarised in the following overview - see Tab. 2 .

Company A is not undergoing any structural change; nor does it have a leading position on the market. The strategy can be classified as rather prudent and the financial goals are selected cautiously. Therefore, we did categorised Company A as a value creator and suggested NPV method for evaluating the investment.

\section{Tab. 2: Financial decision-making indicators}

\begin{tabular}{|c|c|c|}
\hline \multicolumn{2}{|r|}{ Character of the company } & Main indicator \\
\hline \multirow{4}{*}{$\begin{array}{l}\text { Market } \\
\text { creators }\end{array}$} & Emphasis on strategy & \multirow{4}{*}{ Internal rate of return } \\
\hline & Long-term development plans & \\
\hline & No financial constrains (short-term) & \\
\hline & Financial analysis as a supporting method & \\
\hline \multirow{5}{*}{ Refocusers } & Emphasis on short term performance & \multirow{5}{*}{$\begin{array}{l}\text { Discounted cash flow } \\
\text { (DCF) resp. Earnings } \\
\text { per share }\end{array}$} \\
\hline & $\begin{array}{l}\text { Necessity to retain the most important intangible assets } \\
\text { (brand and technology) }\end{array}$ & \\
\hline & $\begin{array}{l}\text { Emphasis on links to corporate strategy and financial } \\
\text { management }\end{array}$ & \\
\hline & Complex financial analysis & \\
\hline & Emphasis on creating value for shareholders & \\
\hline \multirow{6}{*}{$\begin{array}{l}\text { Value } \\
\text { creators }\end{array}$} & Internal performance and creating value for customers & \multirow{6}{*}{$\begin{array}{l}\text { Internal rate of return } \\
\text { resp. DCF }\end{array}$} \\
\hline & Emphasis on internal control & \\
\hline & $\begin{array}{l}\text { Emphasis on links to corporate strategy and financial } \\
\text { management }\end{array}$ & \\
\hline & Very prudent strategy and financial analysis & \\
\hline & Own analytical and control tools & \\
\hline & Narrowly defined financial goals & \\
\hline \multirow{3}{*}{ Restructurers } & Significant cost reduction & \multirow{3}{*}{ Internal rate of return } \\
\hline & Emphasis on performance in a very short period & \\
\hline & Very conservative approach & \\
\hline
\end{tabular}

Source: According to Carr (2010). 
We did provide a calculation of production costs, i.e. the expenditure for one bumblebee nest as follows - see Tab. 3 .

Tab. 3: Production expenditure

\begin{tabular}{|l|c|}
\hline \multicolumn{1}{|c|}{ Items } & EUR/ nest \\
\hline Direct material & 3 \\
\hline Direct wages & 5 \\
\hline Direct production expenditure & 8 \\
\hline
\end{tabular}

Source: Authors' calculation.

The other costs of selling the bumblebee nests are the distribution costs of EUR 0.5 per product. The total promotion and marketing costs are EUR 1.975; the selling price based on market research is EUR 40 each. The marketing department proposes total sales of 450 units in 2014, 650 units in 2015 and 500 units in 2016.

\subsection{Life - cycle perspective of $R \& D$ investment effectiveness}

The NPV of the R\&D project in the context of the life cycle of the bumblebee nest was calculated as follows (see the Tab. 4).

Tab. 4: Life cycle calculation

\begin{tabular}{|c|c|c|c|c|c|}
\hline Items & 2013 & 2014 & 2015 & 2016 & Total \\
\hline Sold units & & 450 & 650 & 500 & 1.600 \\
\hline Income (EUR) & 0 & 18.000 & 26.000 & 20.000 & 64.000 \\
\hline Production expenditure (EUR) & 0 & 3.600 & 5.200 & 4.000 & 12.800 \\
\hline Distribution expenditure (EUR) & 0 & 225 & 325 & 250 & 800 \\
\hline $\begin{array}{l}\text { Promotion and marketing } \\
\text { expenditure (EUR) }\end{array}$ & 0 & 900 & 325 & 750 & 1.975 \\
\hline R\&D expenditure (EUR) & 20.020 & 19.980 & 0 & 0 & 40.000 \\
\hline Total expenditure (EUR) & 20.020 & 24.705 & 5.850 & 5.000 & 55.575 \\
\hline Cash flow (CF) (EUR) & -20.020 & -6.705 & 20.150 & 15.000 & 8.425 \\
\hline Discount rate & 1,000 & 0,952 & 0,907 & 0,864 & \\
\hline DCF (EUR) & -20.020 & -6.386 & 18.277 & 12.958 & 4.828 \\
\hline
\end{tabular}

Source: Authors' calculation. 
Kubáňková, M. - Hyršlová, J.: Life Cycle Perspective of $R \& D$ Investment Management: Case Study Approach.

A discount rate of $5 \%$ was used, that reflects the requirement on the capital investment return of the shareholders.

The Tab. 4 gives the following conclusions:

- The comparison of R\&D expenditure and cash flow generated by the sales of the new product from the life cycle perspective enables the R\&D investment to be evaluated.

- The cash flow forecast for the life cycle of the product provides a clear picture of the contribution of the particular project in the company's value creation.

- The NPV of the particular R\&D project enables to compare the investments in $\mathrm{R} \& \mathrm{D}$ projects with other investment opportunities.

The investment in R\&D should be based on the availability of free internal resources. However, the decision-makers should also have an analysis of the profitability of the investment.

The analysis shows the possibility of using life cycle product perspective to control R\&D investment. The expenditure is compared to the net income generated during the whole life cycle of the product. This complex evaluation allows to meet the requirements of the $R \& D$ management and evaluation and to support the decision-making process (Pearson, 2010).

\section{Discussion and conclusion}

Increasing spending on $\mathrm{R} \& \mathrm{D}$ on the one hand and the need for more frequent innovation on the other hand forces the manager to monitor and evaluate the effectiveness of $R \& D$ expenditure more closely (Pearson, 2010), especially in the development of new products (Chiesa, 2009). The prospect of the product life cycle gives a good framework for evaluating $\mathrm{R} \& \mathrm{D}$ expenditure. The life cycle perspective allows $\mathrm{R} \& \mathrm{D}$ expenditure to be assessed and investments evaluated with the net income generated during the whole product life cycle.

The paper demonstrates the evaluation of $R \& D$ investment for a specific example of a new product in SMEs. Using the life cycle 
perspective the company will gain a tool that will give an evaluation of the $R \& D$ 's effectiveness and provides an opportunity to manage $R \& D$ projects and compare them with others investments.

The cases in our sample suggest that a re-design of measuring $R \& D$ strategy is vital for securing the accountability of R\&D (Chiesa, 2009.) The case study shows the importance of the life - cycle perspective to go with the accounting information and support the strategic decision (Jorgensen - Messner, 2010). On the other hand, there are a few limitations of LCC to be mentioned. Gluch and Baumann (2004) noticed the poor availability and reliability of input data, which implies that the investment decision is made under uncertainty, which means that the decision-maker must make many estimates. When decision-makers are faced with uncertainty they generally make estimations that are biased towards their own values and motives rather than being objective to the problem in hand (Hogarth, 1994 in Gluch - Baumann, 2004).

The main limitation of this research is the chosen method, which cannot be statistically related to multiple cases. The study obviously has some limitations. First, because of the adopted research methodology the results cannot be statistically generalised, they can only be analytically extended to other firms investing in R\&D. Therefore, further research should be carried out to explore other $R \& D$ projects and evaluate the effectiveness with the LCC. The chosen R\&D has a positive environmental impact, which is an interesting avenue for future research that should examine R\&D effectiveness from the environmental perspective.

\section{References}

Ahrens, T. - Chapman, C. (2007): Management Accounting as Practice. Accounting, Organizations and Society, 2007, vol. 32, no. 1-2, pp. 1-27.

Back-Hock, A. (1992): Towards Strategic Accounting in Product Management: Implementing a Holistic Approach in a Data and Methods Base for Managerial Accounting. European Journal of Operational Research, 1992, vol. 61, no. 1-2, pp. 98-105.

Bhimani, A. (2007): Structure, Formality and the Importance of Financial and Non-financial Information in Strategy Development and Implementation. Management Accounting Research, 2007, vol. 18, no. 1, pp. 3-31. 
Kubáňková, M. - Hyršlová, J.: Life Cycle Perspective of R\&D Investment Management: Case Study Approach.

Bremser, G. W. (2004): Utilizing the Balanced Scorecard for $R \& D$ Performance Measurement. R\&D Management, 2004, vol. 34, no. 3, pp. 3.

Brown, M. G. - Svenson, R. A. (1998): Measuring R\&D Productivity. Research - Technology Management, 1998, vol. 41, no. 6, pp. 30-35.

Carr, C. (2010): Strategic Investment Decision Making Practices: A Contextual Approach. Management Accounting Research, 2010, vol. 21, no. 3, pp. 167-184.

Chiesa V. (2009): Performance Measurement in R\&D: Exploring the Interplay between Measurement Objectives, Dimensions of Performance and Contextual Factors. R\&D Management, 2009, vol. 39, no. 5.

Dixon, R. (1998): Accounting for Strategic Management. A Practical Application. Long Range Planning, 1998, vol. 31, no. 2, pp. 272-279.

Dunk, A. (2012): Assessing the Contribution of Product Life Cycle Cost Analysis, Customer Involvement, and Cost Management to the Competitive Advantage of Firms. Advances in Management Accounting, Emerald Group Publishing Limited, 2012, vol. 20, pp. 29 - 45.

Gluch, P. - Baumann, H. (2004): The Life Cycle Costing (LCC) Approach: a Conceptual Discussion of its Usefulness for Environmental Decision-making. Building and Environment, 2004, vol. 39, no. 5, pp. 571-580.

Guilding, Ch. (2000): An International Comparison of Strategic Management Accounting Practices. Management Accounting Research, 2000, vol. 11, no. 1, pp. 113-135.

Harvey, G. (1976): Life-Cycle-Costing: A Review of the Technique. Management Accounting, October 1978, 1976, vol. 14, no. 6, pp. 343347.

Heijungs, R. (2010): Life Cycle Assessment and Sustainability Analysis of Products, Materials and Technologies. Toward a Scientific Framework for Sustainability Life Cycle Analysis. Polymer Degradation and Stability, 2010, vol. 95, no. 3, pp. 422-428.

Hogarth, R. (1994): Judgement and Choice. 2nd ed. Chicago, Wiley, 1994.

Jarzabkowski, P. (2004): Strategy as Practice: Recursiveness, Adaptation and Practices-in-Use. Organization Studies, 2004, vol. 25, no. 4, pp. 529560. 
Jeswani, H. (2010): Options for Broadening and Deepening the LCA Approaches. Journal of Cleaner Production, 2010, vol. 18, no. 2, pp. 120127.

Jorgensen, B. - Messner, M. (2010): Accounting and Strategizing: a Case Study from New Product Development. Accounting, Organizations and Society, 2010, vol. 35, no. 2, pp. 184-204.

Kerssens-van Drongelen, I. - Nixon, B. - Pearson, A. (2000): Performance Measurement in Industrial $R \& D$. International Journal of Management Review, 2000, vol. 2, no. 2, pp. 111-144.

Král, B. et al. (2002): Manažerské účetnictví. Praha, Management Press, 2002.

Lohian, N. (1984): How Companies Manage R\&D: A Survey of Major UK Companies. London, Institute of Cost and Management Accountants, 1984.

Nixon, B. (2012): The Paradox of Strategic Management Accounting. Management Accounting Research, 2012, vol. 23, no. 4, pp. 229-244.

Orlikowski, W. J. (2007): Sociomaterial Practices: Exploring Technology at Work. Organization Studies, 2007, vol. 28, no. 9, pp. 1435-1448.

Pearson, A. W. (2010): $R \& D$ as a Business - What Are the Implications for Performance Measurement. R\&D Management, 2010, vol. 30, no. 4.

Porter, M. (1985): Competitive Advantage: Creating and Sustaining Superior Performance. New York, Free Press, 1985.

Roslender, R. (2003): In Search of Strategic Management Accounting: Theoretical, and Field Study Perspectives. Management Accounting Research, 2003, vol. 14, no. 3, pp. 255-279.

Schatzki, T. R. (2005): The Sites of Organizations. Organization Studies, 2005, vol. 26, no. 3, pp. 465-484.

Seal, W. (2010): Managerial Discourse and the Link between Theory and Practice: From ROI to Value-Based Management. Management Accounting Research, 2010, vol. 21, no. 2, pp. 95-109.

Šoljaková, L. (2007): Strategicky zaměřené manažerské účetnictví. Praha, Management Press, 2007.

Teece, D. J. - Pisano, G. - Shuen, A. (1997): Dynamic Capabilities and Strategic Management. Strategic Management Journal, 1997, vol. 18, no. 7 , pp. 509-533. 
Kubáňková, M. - Hyršlová, J.: Life Cycle Perspective of R\&D Investment Management: Case Study Approach.

Tidd, J. - Bessant, J. (2009): Managing Innovation, Integrating Technological, Market and Organisational Change. 4th ed. Chichester, John Wiley \& Sons, 2009.

Tierlinck, P. (2013): Formal R\&D Management and Strategic Decision Making in Small Firms in Knowledge-Intensive Business Services. R\&D Management, 2013, vol. 43, no. 1.

Whittington, R. (2006): Completing the Practice Turn in Strategy Research. Organization Studies, 2006, vol. 27, no. 5, pp. 613-634.

Woods, M. (2012): Electronics: A Case Study of Economic Value Added in Target Costing. Management Accounting Research, 2012, vol. 23, no. 4, pp. 261-277.

Woodward, D. (1997): Life Cycle Costing - Theory, Information Acquisition and Application. International Journal of Project Management, 1997, vol. 15, no. 6, pp. 335-344.

Wubbenhorst, K. (1986): Life Cycle Costing in Construction Projects. Long Range Planning, 1986, vol. 19, no. 4, pp. 87-97. 


\section{Appendix 1}

\section{Interview - general manager Company A}

Motivation for R\&D projects:

- The plans for new research projects reflect the needs of our customers and the new market trends, which we acquire by participating in specialized exhibitions, conferences and professional journals.

- The company is not a major market player, so each new project and investment is carefully investigated and discussed.

Decisions on R\&D investments and the parameters of the decisions:

- The company owners have the final word on a decision; for their decisions information about the actual financial position of the company and the results of market research are crucial.

- The company will decide on a new project if the financial plans clearly show free financial resources for the investments, the owners require $R \& D$ financing primarily from internal resources (free cash flow).

- The master budget prepared for next year is crucial for meeting the financial goals and targets; adherence to the budget is monitored regularly during the year.

Main advantage of a new product:

- The market demand for bumblebee breeds is arising in the same environment as the plants, which are used by the customers.

- There are not enough such produced breeds on the market, which is the main advantage of the new product and offers significant potential. 


\section{Interview $-\mathbf{R} \& D$ manager}

Main advantage of the new product:

- The bumblebee provided an alternative for pollination and therefore if bumblebee colonies die the laboratory bumblebee can save the crops.

- The origin of bumblebees is important for the landscape; the ideal situation is to plant a nest of bumblebees from the same environment, therefore the Company A will offer to check the bumblebee, which is not yet sufficiently present on the market.

- Breeding bumblebees leads farmers to plant other plants as food for bumblebees - support for other pollinators (bees, butterflies), overall it contributes to the landscape.

Limitation of current technology:

- New technology will probably not absolutely eliminate pests attached to the nest at the beginning phase of establishing the nests at the customers.

- Additional resources would need to be invested at least in 2017.

\section{Interview - financial manager and marketing manager}

Sale price of a new product:

- The sale price was set at 40 EUR / nest.

Method of determining the amount of production expenses per nest:

- The production of bumblebee nests is challenging in particular for the technicians and laboratory technicians; the preliminary calculation was determined:

- The time to produce one nest (total nest handling time, change of food, washing, preparation and evidence) approx. 45 min, so 5 EUR / 1 nest. 
- Pollen, sugar and pads of 3 EUR / 1 nest are needed to produce one nest.

Organization of product distribution and promotion and marketing costs:

- The bumblebee nests are shipped in special equipped hives, the cost is 0.5 EUR per unit and they are prepared to be picked up either at the Company A or can be posted to the customers (the delivery costs are covered by the customer).

- The total promotion and marketing costs of this product was calculated at 1.975 EUR in the given period.

- According to the market research result the Company A is planning to sell 450 units in 2014, 650 units in 2015 and 500 units in 2016. 
Kubáňková, M. - Hyršlová, J.: Life Cycle Perspective of $R \& D$ Investment Management: Case Study Approach.

\section{Appendix 2}

Financial statements of Company A

\begin{tabular}{|l|r|r|r|}
\hline BALANCE SHEET in EUR & \multicolumn{1}{|c|}{$\mathbf{2 0 1 3}$} & \multicolumn{1}{c|}{$\mathbf{2 0 1 2}$} & \multicolumn{1}{c|}{$\mathbf{2 0 1 1}$} \\
\hline TOTAL ASSETS & 535.835 & 519.408 & 484.872 \\
\hline FIXED ASSETS & 355.793 & 342.322 & 320.820 \\
\hline Intangible assets & 5.382 & 5.082 & 5.410 \\
\hline Tangible assets & 339.818 & 326.147 & 303.393 \\
\hline Financial assets & 10.593 & 11.094 & 12.017 \\
\hline CURRENT ASSETS & 179.779 & 176.603 & 163.251 \\
\hline Inventory & 1.905 & 2.526 & 2.898 \\
\hline Non-current receivables & 812 & 665 & 2.115 \\
\hline Current receivables & 150.580 & 147.708 & 156.325 \\
\hline Financial assets & 26.482 & 25.704 & 1.913 \\
\hline OTHER ASSETS & 263 & 483 & 801 \\
\hline TOTAL LIABILITIES & 535.835 & 519.408 & 484.872 \\
\hline EQUITY & 268.533 & 244.165 & 230.219 \\
\hline Share capital & 101.982 & 101.982 & 101.982 \\
\hline Capital funds & 11.271 & 11.259 & 11.018 \\
\hline Reserves & 126.431 & 106.091 & 96.875 \\
\hline Retained earnings & 0 & 0 & 0 \\
\hline Current year result (+/-) & 28.850 & 24.834 & 20.345 \\
\hline LIABILITIES & 227.890 & 238.681 & 221.322 \\
\hline Provisions & 12.121 & 20.138 & 14.723 \\
\hline Non-current liabilities & 22.442 & 21.655 & 18.186 \\
\hline Current liabilities & 193.327 & 195.387 & 179.371 \\
\hline Bank loans and other loans & 0 & 1.500 & 9.043 \\
\hline OTHER LIABILITIES & 39.412 & 36.562 & 33.331 \\
\hline
\end{tabular}




\begin{tabular}{|l|r|r|r|}
\hline \multicolumn{1}{|c|}{$\begin{array}{c}\text { PROFIT AND LOSS } \\
\text { in EUR }\end{array}$} & \multicolumn{1}{c|}{$\mathbf{2 0 1 3}$} & \multicolumn{1}{c|}{$\mathbf{2 0 1 2}$} & \multicolumn{1}{c|}{$\mathbf{2 0 1 1}$} \\
\hline Sales & 473.805 & 487.863 & 448.670 \\
\hline Cost of sales & 384.202 & 403.069 & 374.908 \\
\hline VALUE ADDED & 89.603 & 84.794 & 73.761 \\
\hline Wages and salaries & 28.808 & 26.292 & 24.914 \\
\hline Taxes and fees & 632 & 418 & 330 \\
\hline Depreciation & 26.771 & 24.906 & 23.337 \\
\hline Profit on sales of fixed assets & 1.876 & 4.540 & 2.889 \\
\hline NBV of sold fixed assets & 1.102 & 3.178 & 2.128 \\
\hline Release of provisions & -2.450 & 5.889 & 5.400 \\
\hline Other operating income & 3.745 & 34.983 & 34.788 \\
\hline Other operating expenses & 2.357 & 28.854 & 27.667 \\
\hline Operating result & 38.004 & 34.793 & 27.551 \\
\hline Financial result & 698 & 721 & 52 \\
\hline Income tax & 9.852 & 10.668 & 7.147 \\
\hline Profit after tax & 28.850 & 24.833 & 20.345 \\
\hline Extraordinary result & 0 & 13 & -111 \\
\hline Current year result & 28.850 & 24.834 & 20.345 \\
\hline EBIT & 38.702 & 35.501 & 27.491 \\
\hline
\end{tabular}

\begin{tabular}{|l|r|r|r|}
\hline \multicolumn{1}{|c|}{ CASH FLOW in EUR } & \multicolumn{1}{c|}{$\mathbf{2 0 1 3}$} & \multicolumn{1}{c|}{$\mathbf{2 0 1 2}$} & \multicolumn{1}{c|}{$\mathbf{2 0 1 1}$} \\
\hline Net operating cash flow & 24191 & 63854 & 54404 \\
\hline Net investing cash flow & -17510 & -21496 & -50685 \\
\hline Net financial cash flow & -5902 & -18567 & -2154 \\
\hline Net cash flow & 779 & 23791 & 1565 \\
\hline $\begin{array}{l}\text { Cash and cash equivalents }- \\
\text { opening balance }\end{array}$ & 25704 & 1913 & 348 \\
\hline $\begin{array}{l}\text { Cash and cash equivalents }- \\
\text { closing balance }\end{array}$ & 26483 & 25704 & 1913 \\
\hline
\end{tabular}

Source: Company A data. 


\title{
Life Cycle Perspective of R\&D Investment Management: Case Study Approach
}

\begin{abstract}
The management of $R \& D$ activities has become popular among researchers. The need for changes in $R \& D$ organization and financial support brings new decision-making issues for the R\&D manager. Life cycle concepts help to manage $R \& D$ in the whole perspective. The aim of this paper was to examine the life cycle costing for R\&D investment appraisal. A case study was realised in a private SME company for the $\mathrm{R} \& \mathrm{D}$ project of the bumblebee laboratory production. The analysis showed the possibility of using life cycle product perspective to control R\&D investment. The expenditure was compared to the net income generated during the whole life cycle of the product. This complex evaluation allows to meet the requirements of the R\&D management and to support the decision-making process. Using the life cycle perspective the company will gain a tool that will give an evaluation of the R\&D's effectiveness and provides an opportunity to manage $R \& D$ projects and compare them with others investments.
\end{abstract}

Key words: Life cycle costing; R\&D investment; Strategic management accounting.

JEL classification: M21 